\title{
Analysis of Students' Mathematical Problem Solving Ability in terms of Student Learning Styles with Models Problem Based Learning
}

\author{
Dwi Ardy Dermawan ${ }^{1}$, Pargaulan Siagian², Bornok Sinaga ${ }^{3}$ \\ ${ }^{1,2,3}$ Universitas Negeri Medan, Indonesia \\ dwiad.math@gmail.com
}

\begin{abstract}
This study aims to analyze and determine: (1) the level of mathematical problem solving ability in terms of learning styles after implementing problem-based learning; (2) errors and difficultiesexperienced by students in solving math problem solving abilities in terms of learning styles after implementing problem-based learning. This research is a descriptive qualitative research. The subjects of this study were 32 students of SMA Negeri 1 Rantau Selatan class X MIPA 1, who were then appointed to interview subjects based on the Kolb \& Kolb learning style, namely accommodation, divergent, assimilation, and convergent based on the level obtained based on indicators and aspects of difficulty. The research results are as follows: (1) there are 8 students (25\%) has a learning style accommodation with the level of mathematical problem solving ability medium category amounted to 3 students, and low category amounted to 5 students; there are 11 students(34.37\%) have a divergent learning style with a level of mathematical problem solving ability 1 student in high category, 4 students in medium category, 6 students in low category; exist 9 students (28.13\%) have an assimilating learning style with a level of mathematical problem solving ability medium category amounted to 2 students, and low category amounted to 7 people; exist 4 students $(12.5 \%)$ have a convergent learning style with a level of mathematical problem solving ability medium category amounted to 3 students, with the low category amounted to 1 student;(2) for students' difficulties with accommodation learning styles, students have difficulty on principle indicators; for the difficulties of students with divergent learning styles, students have difficulty on indicators of concepts and principles; for the difficulties of students with assimilation learning styles, students have difficulty in the concept indicators and indicators of verbal problems; for the difficulty of students with convergent learning styles, students have difficulty on principle indicators.
\end{abstract}

Keywords mathematics problem solving ability; problem based learning model; Kolb \& Kolb learning style

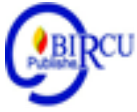

\section{Introduction}

Mathematics is a tool for developing ways of thinking, having abstract objects, deductive thinking, and dealing with structural ideas arranged in a logical structure. Meanwhile, as a science, mathematics needs to be taught to humans to make it easier to carry out each of their activities. Irhamna (2020) argues that mathematics is a universal science. Mathematics is also seen as the queen of science. Besides that, it is also a step to develop mathematics as a science. This teaching is of course carried out through formal education which is linked to human daily life. Mathematics in this case is known as school 
mathematics. School mathematics, or mathematics for academic purposes, should be viewed as a learning that requires student action (learning by doing). Although mathematics in general is abstract.

The ability to solve problems is still one of the abilities that are considered in mathematics learning in schools. Hooda and Devi (2014: 1774) state that problem solving is the key to success and has been considered the most important aspect of human behavior. One of the main goals of education is to develop the ability to achieve better performance. No two individuals are the same. There are individual differences in problem solving abilities. Some individuals can handle a situation, but others cannot. Much of an individual's life is spent struggling to find effective solutions to problems. Students who have good problem-solving skills are well adapted to both in class and at home. Problems cannot be resolved without thinking. The need for problem-solving behavior is to create thinking powers that help find solutions to problems. The main goal of problem solving is through physical, psychological, social and environmental factors that hinder one's progress towards achieving certain goals.

The ability to solve problems is still one of the abilities that are considered in mathematics learning in schools. Hooda and Devi (2014: 1774) state that problem solving is the key to success and has been considered the most important aspect of human behavior. One of the main goals of education is to develop the ability to achieve better performance. No two individuals are the same. There are individual differences in problem solving abilities. Some individuals can handle a situation, but others cannot. Much of an individual's life is spent struggling to find effective solutions to problems. Students who have good problem-solving skills are well adapted to both in class and at home. Problems cannot be resolved without thinking. The need for problem-solving behavior is to create thinking powers that help find solutions to problems. The main goal of problem solving is through physical, psychological, social and environmental factors that hinder one's progress towards achieving certain goals.

According to Argarini (2018: 93), there are many methods or stages that can be used as a basis for solving problems, one of which is Polya's problem solving method. Polya stated that there were several steps to solve the problem, namely: (1) understanding the problem, (2) drawing up a settlement plan, (3) implementing the settlement plan, and (4) checking again. The process of solving problems between individuals must be different, this is due to habits, understanding of concepts, and styles of each individual. One thing that distinguishes the way of solving problems is the learning style.

Sundayana (2016: 76) also states that one of the efforts that teachers can make to improve students' problem-solving abilities and learning independence is to create a learning atmosphere that matches the type of student learning style (auditory, visual, or kinesthetic), so it is hoped that learning objectives can be achieved effectively. Basically, every student has a different learning style. Pohan (2020) stated that the above description shows that the problem solving approach is the focus in learning mathematics. To improve the ability to solve problems, skills need to be developed to understand problems, create mathematical models, solve problems, and interpret solutions. From this, it will have an impact on the diversity of students in the way they learn. In this case the teacher must be able to understand the students in delivering the subject matter. By paying attention to differences in learning styles, it is possible for students to be able to increase their concentration, so that they tend to get more and more meaningful material.

Learning style is one of the important variables and is related to the way students understand lessons in school, especially mathematics. The learning style of each student is 
certainly different from one another. Because of the different learning styles of students, it is very important for teachers to analyze their students' learning styles so that information can be obtained that can help teachers to be more sensitive in understanding differences in the classroom and be able to carry out meaningful learning.

According to Sugiharto (2020) education is one of the efforts to improve the ability of human intelligence, thus he is able to improve the quality of his life. Education is the most important thing for the development of a nation's civilization. In setting up a stable education system, of course, it takes a long and tiring process to achieve high quality standards (Junifran, 2020). Student learning styles according to Kolb as quoted by Ramadan, et al., (2011: 1-2) are based on 4 stages of learning. Most people go through these steps in the sequence of concrete experiences, reflective, observation, abstract conceptualization, and active experimentation. This means that students have real experiences, then observe then reflect on it from various points of view, then form abstract concepts and generalize into theories and finally actively experience these theories and test what they have learned in complex situations. Learning styles based on these four learning styles include converger, diverger, accommodator, and assimilator learning styles. Identification of student learning styles by the teacher is very important. This is because students who know the type of their learning style will adapt themselves to classroom learning in order to be successful in learning. Meanwhile, the identification of learning styles according to Bhat (2014: 1) can help students to become effective problem solvers. Furthermore, Ozgen, et al. (2011: 182) states that their own learning style is one of the factors that affect how students learn mathematics.

The problem solving ability that is still lacking needs to be studied further to find out how the problem solving ability for each student with different learning styles. In order for the description of students' problem-solving abilities to be better known, in this study students were directed to use the problem-solving stage according to Polya, which was given through problem-based learning.

Based on the background description above, it is necessary to have further research regarding the Analysis of Student Problem Solving Ability based on Student learning styles in Problem Based Learning. This research is expected to be an in-depth study of students' problem solving abilities and student learning styles in the context of Problem Based Learning.

\section{Research Methods}

This type of research is descriptive-qualitative research, which means that it describes or describes the events that are the center of attention (problem solving abilities, student learning styles) qualitatively and based on qualitative data. Denzin and Lincoln (in Moleong, 2017: 5) state that qualitative research is research that uses a natural setting, with the intention of interpreting phenomena that occur and are carried out by involving various existing methods.

The subjects in this study were students of class X MIPA 1 SMA N 1 Rantau Selatan for the 2020/2021 learning year who would be given problem-based learning treatment in the odd semester of the 2020/2021 learning year, totaling 32 people. All of these students were the subject of the learning style questionnaire and the subject of the problem solving ability test but only a few students were the subject of the problem solving ability interview. Research subjects are informants to obtain a classification of the type of learning style and a description of students' problem solving abilities with learning styles in the context of problem-based learning. 
The appointment of the subject to be interviewed is based on observations of student answer sheets in terms of aspects of ability indicators, aspects of errors, aspects of unique answers, and student learning styles. Interview subjects are selected based on a review of each answer classification, then interviews are conducted with these students with the consideration that these students are considered people who can provide data clearly, correctly and reliably. If the data obtained is incomplete, another subject who is subjected to an interview is appointed again in the hope that it can provide more complete information, and so on so that conclusions can be drawn and students' problem-solving abilities can be described.

\section{Results and Discussion}

Based on the results of filling out the learning style questionnaire that has been carried out by 32 students of class X MIPA 1 SMA Negeri 1 Rantau Selatan, the learning style results are shown in the table below:

Table 1. Student Learning Style Questionnaire Results

\begin{tabular}{|l|c|c|}
\hline Learning Style & $\begin{array}{c}\text { The number of } \\
\text { students }\end{array}$ & Percentage \\
\hline Accommodation & 8 people & $25 \%$ \\
\hline Divergent & 11 People & $34.37 \%$ \\
\hline Assimilation & 9 Person & $28.13 \%$ \\
\hline Convergent & 4 people & $12.5 \%$ \\
\hline
\end{tabular}

Based on Table 1, it is found that students who occupy each of the Kolb \& Kolb learning styles. Students classified into accommodation learning styles are 8 students (25\%). There are 11 students classified into Divergent learning styles (34.37\%). There are 9 students classified into the Assimilation learning style person(28.13\%). There are 4 students classified into Convergent learning styles $(12.5 \%)$. below:

The level of problem solving ability in students' mathematics can be seen in Table 2

Table 2. Levels of Students' Mathematical Problem Solving Ability

\begin{tabular}{|c|c|c|c|}
\hline Value Interval & $\begin{array}{c}\text { The number } \\
\text { of students }\end{array}$ & Percentage & $\begin{array}{c}\text { Assessment } \\
\text { criteria }\end{array}$ \\
\hline $0 \leq$ Score $\leq 50$ & 19 people & $59.37 \%$ & Low \\
\hline $50<$ Score $\leq 80$ & 12 people & $37.5 \%$ & Moderate \\
\hline $80<$ Score $\leq 100$ & 1 person & $3.13 \%$ & High \\
\hline
\end{tabular}

Based on the results of grouping student learning styles, the class X MIPA 1 SMA Negeri 1 Rantau Selatan with the accommodation learning style consists of 8 people. Based on the results of the test of students 'mathematical problem solving abilities, the level of students' mathematical problem solving abilities was obtained with an accommodation learning style as in Table 3 below. 
Table 3. Levels of Students' Mathematical Problem Solving Ability with Accommodation Learning Style

\begin{tabular}{|c|c|c|c|}
\hline Value Interval & $\begin{array}{c}\text { The number } \\
\text { of students }\end{array}$ & Percentage & Rating Category \\
\hline $0 \leq$ Score $\leq 50$ & 5 people & $62.5 \%$ & Low \\
\hline $50<$ Score $\leq 80$ & 3 people & $37.5 \%$ & Moderate \\
\hline $80<$ Score $\leq 100$ & - & $0 \%$ & High \\
\hline
\end{tabular}

Based on the results of grouping student learning styles, the class X MIPA 1 SMA Negeri 1 Rantau Selatan with divergent learning styles consisted of 11 people. Based on the test results of students' problem solving abilities in mathematics, the level of problem solving abilities in mathematics of students with divergent learning styles is obtained as in Table 4 below.

Table 4. Levels of Problem Solving Ability Student Mathematics with Divergent Learning

\begin{tabular}{|c|c|c|c|}
\hline Value Interval & $\begin{array}{c}\text { The number } \\
\text { of students }\end{array}$ & Percentage & Rating Category \\
\hline $0 \leq$ Score $\leq 50$ & 6 people & $54.55 \%$ & Low \\
\hline $50<$ Score $\leq 80$ & 4 people & $36.36 \%$ & Moderate \\
\hline $80<$ Score $\leq 100$ & 1 person & $9.09 \%$ & High \\
\hline
\end{tabular}

Based on the results of grouping student learning styles, class X MIPA 1 SMA Negeri 1 Rantau Selatan with an assimilated learning style consisted of 9 people. Based on the test results of students' problem-solving abilities in mathematics, the level of problemsolving abilities in mathematics of students with assimilation learning styles is obtained as in Table 5 below.

Table 5. Levels of Problem Solving Ability Student Mathematics with Assimilated Learning Styles

\begin{tabular}{|c|c|c|c|}
\hline Value Interval & $\begin{array}{c}\text { The number } \\
\text { of students }\end{array}$ & Percentage & Rating Category \\
\hline $0 \leq$ Score $\leq 50$ & 7 people & $77.78 \%$ & Low \\
\hline $50<$ Score $\leq 80$ & 2 persons & $22.22 \%$ & Moderate \\
\hline $80<$ Score $\leq 100$ & - & $0 \%$ & High \\
\hline
\end{tabular}

Based on the results of grouping student learning styles, the class X MIPA 1 SMA Negeri 1 Rantau Selatan with a convergent learning style consisted of 4 people. Based on the test results of students' problem solving abilities in mathematics, the level of problem solving abilities in mathematics of students with convergent learning styles is obtained as in Table 6 below.

Table 6. Levels of Students' Mathematical Problem Solving Ability with Convergent Learning Styles

\begin{tabular}{|c|c|c|c|}
\hline Value Interval & $\begin{array}{c}\text { The number } \\
\text { of students }\end{array}$ & Percentage & Rating Category \\
\hline $0 \leq$ Score $\leq 50$ & 1 person & $25 \%$ & Low \\
\hline $50<$ Score $\leq 80$ & 3 people & $75 \%$ & Moderate \\
\hline $80<$ Score $\leq 100$ & - & - & High \\
\hline
\end{tabular}


Based on the description of the errors and difficulties experienced by students with the accommodation learning style in solving problems solving problems in mathematics, students will summarize the difficulties experienced by each student.

Table 7. Difficulties Experienced by Students with Accommodation Learning Styles in Resolving Kemampuan Solving Math Problems

\begin{tabular}{|c|c|c|c|}
\hline \multirow{2}{*}{ Student Error } & \multicolumn{3}{|c|}{ Aspects of Difficulties Experienced by Students } \\
\cline { 2 - 4 } & $\begin{array}{c}\text { Concept } \\
\text { Indicators }\end{array}$ & $\begin{array}{c}\text { Principle } \\
\text { Indicators }\end{array}$ & $\begin{array}{c}\text { Indicator of } \\
\text { Verbal Problems }\end{array}$ \\
\hline Low & - & $\ddot{O}$ & - \\
\hline Moderate & - & $\ddot{O}$ & - \\
\hline
\end{tabular}

Based on the description of the errors and difficulties experienced by students with divergent learning styles in solving problems, the students' mathematical problem solving abilities will be summarized the difficulties experienced by each student.

Table 8. Difficulties Experienced by Students with Divergent Learning Styles in Solving Mathematical Problem Solving Ability Problems

\begin{tabular}{|c|c|c|c|}
\hline \multirow{2}{*}{ Student Error } & \multicolumn{3}{|c|}{ Aspects of Difficulties Experienced by Students } \\
\cline { 2 - 4 } & $\begin{array}{c}\text { Concept } \\
\text { Indicators }\end{array}$ & $\begin{array}{c}\text { Principle } \\
\text { Indicators }\end{array}$ & $\begin{array}{c}\text { Indicator of } \\
\text { Verbal Problems }\end{array}$ \\
\hline Low & $\ddot{O}$ & $\ddot{O}$ & - \\
\hline Moderate & $\ddot{O}$ & - & - \\
\hline High & - & $\ddot{O}$ & \multicolumn{2}{|c}{} \\
\hline
\end{tabular}

Based on the description of the errors and difficulties experienced by students with the assimilation learning style in solving problems solving problems in mathematics, students will summarize the difficulties experienced by each student.

Table 9. Difficulties Experienced by Students with Assimilated Learning Styles in Solving Mathematical Problem Solving Ability Problems

\begin{tabular}{|c|c|c|c|}
\hline \multirow{2}{*}{ Student Error } & \multicolumn{3}{|c|}{ Aspects of Difficulties Experienced by Students } \\
\cline { 2 - 4 } & $\begin{array}{c}\text { Concept } \\
\text { Indicators }\end{array}$ & $\begin{array}{c}\text { Principle } \\
\text { Indicators }\end{array}$ & $\begin{array}{c}\text { Indicator of } \\
\text { Verbal Problems }\end{array}$ \\
\hline Low & - & - & Ö \\
\hline Moderate & $\ddot{O}$ & - & - \\
\hline
\end{tabular}

Based on the description of the errors and difficulties experienced by students with convergent learning styles in solving problems, the students' problem solving abilities in mathematics will be summarized the difficulties experienced by each student.

Table 10. Difficulties Experienced by Students with Converged Learning Styles in Solving Mathematical Problem Solving Ability Problems

\begin{tabular}{|c|c|c|c|}
\hline \multirow{2}{*}{ Student Error } & \multicolumn{3}{|c|}{ Aspects of Difficulties Experienced by Students } \\
\cline { 2 - 4 } & $\begin{array}{c}\text { Concept } \\
\text { Indicators }\end{array}$ & $\begin{array}{c}\text { Principle } \\
\text { Indicators }\end{array}$ & $\begin{array}{c}\text { Indicator of Verbal } \\
\text { Problems }\end{array}$ \\
\hline Low & - & $\sqrt{ }$ & - \\
\hline Moderate & - & $\sqrt{ }$ & - \\
\hline
\end{tabular}




\section{Conclusion}

Based on the research, from 32 students of class X MIPA 1 SMA Negeri 1 Rantau Selatan, the students' level of mathematical problem solving ability was obtained:

1. With the accommodation learning style, namely There are 3 students in the medium category and 5 students in the low category.

2. With a divergent learning style, namely There are 1 student in the high category, 4 students in the medium category, and 6 students in the low category.

3. With the assimilation learning style, namely There are 2 students in the medium category, and 7 students in the low category.

4. With a convergent learning style, namely students with the medium assessment category amounted to 3 students, and with the low assessment category amounted to 1 student.

Difficulties experienced by students in solving problems of students' mathematical problem solving abilities:

1. Students with accommodation learning styles have difficulty on principle indicators.

2. Students with divergent learning styles have difficulty in concept indicators and principle indicators.

3. Students with assimilationist learning styles have difficulty in concept indicators and indicators of verbal problems

4. Students with convergent learning have difficulty on principle indicators.

\section{References}

Argarini, D. F. 2018. Analisis Pemecahan Masalah Berbasis Polya pada Materi Perkalian Vektor Ditinjau dari Gaya Belajar. Jurnal Matematika dan Pembelajaran, vol 6, No. 1, 91-99.

Bhat, MA 2014. The Effect of Learning Style on Problem Solving Ability among High School Students. International Journal Advances in Social Science and Humanities, vol 2 (7), 1-6.

Hooda, M. and Devi, R. 2014. Problem Solving Ability: Significance for Adolescents. Scholarly Research Journal for Interdisciplinary Studies, vol II / XIII, 1773-1778.

Irhamna, Amry., and Syahputra H. (2020). Contribution of Mathematical Anxiety, Learning Motivation and Self-Confidence to Student's Mathematical Problem Solving. Budapest International Research and Critics in Linguistics and Education (BirLE) Journal Vol 3 (4): 1759-1772.

Moleong, Lexy J. 2013. Metode Penelitian Kualitatif. Edisi Revisi. Bandung : PT. Remaja Rosdakarya

Ozgen K., et al. 2011. An Examination of Multiple Intelligence Domains and Learning Styles of Pre-Service Mathematics Teachers: Their Reflections on Mathematics Education. Educational Research and Reviews Journal, vol 6 (2), 168-181.

Pohan, A.M., Asmin, and Menanti, A. (2020). The Effect of Problem Based Learning and Learning Motivation of Mathematical Problem Solving Skills of Class 5 Students at SDN 0407 Mondang. Budapest International Research and Critics in Linguistics and Education (BirLE) Journal Vol 3 (1): 531-539.

Ramadan, et al. 2011. An Investigation of The Learning Style of Prospective Educators. The Online Journal of New Horizons in Education, 1, 1-6. 
Sundayana, R. 2016. Kaitan antara Gaya Belajar, Kemandirian Belajar, dan Kemampuan Pemecahan Masalah Siswa SMP dalam Pelajaran Matematika. Jurnal Moshrafa, Vol. 5, No. $2: 75-84$.

Sugiharto. (2020). Geographical students' learning outcomes on basic political science by using cooperative learning model with Group Investigation (GI) type in State University of Medan, Indonesia, Journal of Human Behavior in the Social Environment, 30:4, 447-456, DOI: 10.1080/10911359.2019.1696261.Sukarti. H. 